Web Jurnal:

http://ejournal.kemenperin.go.id/jli

Kementerian

Perindustrian

REPUBLIK INDONESIA
Jurnal Litbang Industri

p-ISSN: 2252-3367 | e-ISSN: 2502-5007 |

\title{
Uji sifat fisikokimia gelatin yang diisolasi dari tulang ikan kembung (Rasterelliger sp.) menggunakan beberapa jenis larutan asam
}

\section{Physicochemical properties of gelatin isolated from long jawed mackerel fish bone (Rasterelliger sp.) using various acid solution}

\author{
Nurlela Nurlela*, Lany Nurhayati, dan Eka Lindawati \\ Jurusan Kimia, Fakultas Matematika dan Ilmu Pengetahuam Alam, Universitas Nusa Bangsa \\ J1. KH. Sholeh Iskandar KM. 4, Cimanggu, Tanah Sereal, Bogor, Jawa Barat 16166, Indonesia \\ *e-mail: nurlela.kimia@gmail.com
}

\begin{tabular}{l}
\hline INFO ARTIKEL \\
\hline Sejarah artikel: \\
Diterima : \\
29 Januari 2021 \\
Direvisi : \\
06 Juni 2021 \\
Diterbitkan : \\
30 Juni 2021
\end{tabular}

\section{Kata kunci:}

tulang ikan kembung;

gelatin;

variasi asam;

sifat fisikokimia

\begin{abstract}
ABSTRAK
Salah satu upaya peningkatan nilai ekonomi limbah tulang ikan adalah mengolahnya menjadi gelatin. Ikan kembung merupakan ikan yang relatif murah, digemari masyarakat dan mengandung protein tinggi. Untuk menghasilkan gelatin berkualitas baik diperlukan optimasi pengolahan diantaranya yaitu variasi konsentrasi dan jenis larutan asam serta waktu ekstraksi. Tujuan penelitian ini adalah mencari perlakuan asam terbaik pada proses demineralisasi dan waktu terbaik pada proses ekstraksi dengan aquades menggunakan two-ways ANOVA, serta menguji sifat fisikokimia gelatin dari rendemen tertinggi. Pelarut asam yang digunakan adalah asam klorida $(\mathrm{HCl})$, asam sulfat $\left(\mathrm{H}_{2} \mathrm{SO}_{4}\right)$, dan asam asetat $\left(\mathrm{CH}_{3} \mathrm{COOH}\right)$ dengan konsentrasi masing-masing 2, 4 dan $6 \% \mathrm{v} / \mathrm{v}$. Variasi waktu ekstraksi yaitu 2, 4 dan 6 jam. Hasil penelitian menunjukkan bahwa rendemen tertinggi diperoleh dari perendaman dengan $\mathrm{H}_{2} \mathrm{SO}_{4} 4 \%$ dengan waktu ekstraksi selama 6 jam yaitu $4,27 \%$. Gelatin tersebut memiliki sifat fisikokimia: $\mathrm{pH} 4,0$, titik leleh $28-31,2{ }^{\circ} \mathrm{C}$, titik isoelektrik 9,0, viskositas 2,8 cPs, bobot molekul relatif sebesar 38.390,9 g/mol, kadar air 9,30\%, kadar abu 23,85\%, kadar protein 58,37\%, kadar lemak 0,86\% dan kadar karbohidrat 7,63\%. Analisis FTIR dari gelatin yang dihasilkan menunjukkan gugusgugus fungsi $\mathrm{O}-\mathrm{H}, \mathrm{C}-\mathrm{H}, \mathrm{C}-\mathrm{N}, \mathrm{C}=\mathrm{O}$, dan $\mathrm{N}-\mathrm{H}$ yang sama dengan gelatin komersial. Namun, masih diperlukan optimasi seperti suhu ekstraksi agar gelatin hasil isolasi memenuhi standar mutu.
\end{abstract}

\begin{abstract}
One of the attempts to increase the economic value of fish bone waste is to process it into gelatin. Long jawed mackerel is relatively inexpensive, popular with the public, and high in protein. To produce good quality gelatin, optimization of processing is required, including variations in concentration and type of acid solution and extraction time. The purpose of this study was to find the best acid treatment in the demineralization process and the best time in the extraction process using aquadest used two-ways ANOVA, and to study the physicochemical properties of gelatin from the highest yield. The acidic solvents used were $\mathrm{HCl}, \mathrm{H}_{2} \mathrm{SO}_{4}$, and $\mathrm{CH} 3 \mathrm{COOH}$ with concentrations of 2,4 and $6 \% \mathrm{v} / \mathrm{v}$, respectively. The extraction time varied between 2, 4 and 6 hours. The results showed that the highest yield was obtained by immersion in $4 \% \mathrm{H}_{2} \mathrm{SO}_{4}$ with extraction time of 6 hours (4.27\%). The gelatin has the following physicochemical properties: $p H$ 4.0, melting point $28-31.2^{\circ} \mathrm{C}$, isoelectric point 9.0, viscosity $2.8 \mathrm{cPs}$, relative molecular weight of $38,390.9 \mathrm{~g} / \mathrm{mol}$, water content of $9.30 \%$, 23.85\% ash content, $58.37 \%$ protein content, $0.86 \%$ fat content and $7.63 \%$ carbohydrate content. FTIR analysis of the resulting gelatin showed the same functional groups $\mathrm{O}-\mathrm{H}, \mathrm{C}-\mathrm{H}, \mathrm{C}-\mathrm{N}, \mathrm{C}=\mathrm{O}$ and $\mathrm{N}-\mathrm{H}$ as commercial gelatin. However, there is still a need for optimisation, e.g. at the extraction temperature, so that the gelatin from the isolation meets the quality standard.
\end{abstract}




\section{Pendahuluan}

Gelatin adalah turunan protein dari serat kolagen yang diperoleh dengan cara hidrolisis parsial kolagen yang diperoleh dari kulit, jaringan ikat putih, dan tulang hewan (Ditjen POM, 2012). Selama ini sumber utama gelatin yang banyak dikomersialkan berasal dari kulit dan tulang sapi, atau babi. Produksi gelatin di seluruh dunia mencapai 300.000 ton/tahun (Arief, 2016). Gelatin diproduksi dari kulit babi sebesar 46\%, kulit sapi $29,4 \%$, daging dan tulang babi $23,1 \%$, dan sumber lainnya $1,5 \%$ (Fasya et al., 2018).

Pemenuhan kebutuhan gelatin di Indonesia didapatkan melalui impor dari beberapa negara seperti Cina, Australia, dan beberapa negara di Eropa (Agustin, 2013). Berdasarkan data Badan Pusat Statistik, jumlah impor gelatin pada bulan Februari 2014 mencapai 601.681 Kg (BPS, 2016). Ketergantungan industri farmasi yang berada di Indonesia terhadap impor bahan baku obat masih sangat tinggi, salah satunya adalah cangkang kapsul (Faridah and Susanti, 2018). Cangkang kapsul umumnya terbuat dari gelatin tetapi dapat juga terbuat dari pati atau bahan lain yang sesuai (Ditjen POM, 2012).

Salah satu bahan yang memiliki prospek yang baik untuk membuat gelatin adalah limbah tulang ikan. Gelatin dapat ditemukan di bagian tertentu dari ikan, misalnya tulang dan kulit yang mengandung kolagen. Kolagen dapat dikonversikan menjadi gelatin dengan penambahan perlakuan asam, alkali, atau secara enzimatis (Hidayat et al., 2016). Kandungan kolagen sebagai sumber gelatin pada tulang ikan keras (Teleostei) berkisar 15\% - 17\%, sedangkan pada tulang ikan rawan (Elasmobranch) seperti ikan kembung berkisar 22\% - 24\% (Wulandari et al., 2019). Gelatin dari ikan bisa berkualitas setara dengan babi jika pengolahannya tepat dan akurat (Lin et al., 2017). Berdasarkan proses pembuatannya terdapat dua jenis gelatin yaitu Tipe A dan Tipe B. Gelatin Tipe A diproduksi melalui proses asam sedangkan Tipe B diproduksi melalui proses basa (Darwin et al., 2018).

Limbah tulang ikan ini umumnya masih belum diolah secara optimal, yaitu digunakan untuk bahan pembuatan pakan ternak atau pupuk (Arisanti et al., 2021). Beberapa penelitian mengenai ekstrak gelatin dari tulang ikan telah dilakukan. Namun, masih terbatas pada beberapa variabel, seperti jenis tulang ikan yang digunakan, asam yang digunakan, konsentrasi asam. Perendaman menggunakan larutan asam sitrat dengan berbagai konsentrasi dan waktu telah dilakukan pada tulang ikan pari mondol dan pada tulang ikan patin (Santoso et al., 2015; Pertiwi et al., 2018). Perendaman menggunakan asam klorida juga telah dilakukan terhadap limbah tulang ikan tuna (Panjaitan, 2016) dan tulang ikan nila merah (Arima and Fithriyah, 2015) dengan variasi waktu perendaman asam.

Limbah tulang ikan yang dipilih dalam penelitian ini adalah limbah tulang ikan kembung (Rasterelliger $s p$.). Hal ini dikarenakan ikan kembung termasuk salah satu ikan yang relatif murah dengan kandungan protein yang tinggi berkisar 22\% (Mustadir, 2015) dan cukup digemari oleh masyarakat. Sedangkan penggunaan asam sebagai larutan untuk demineralisasi karena larutan asam lebih efektif dalam mengubah serat kolagen dengan struktur triple helix menjadi rantai tunggal yang terkandung dalam sampel tulang ikan (Yenti et al., 2015). Masih sedikitnya penelitian mengenai pengaruh akan variasi jenis larutan asam yang digunakan dan perbedaan lamanya waktu ekstraksi yang digunakan terhadap pembuatan gelatin hasil dari ekstraksi tulang ikan, serta penggunaan limbah tulang ikan kembung yang belum banyak diteliti ini menjadi alasan utama dilakukannya penelitian ini.

Tujuan dari penelitian ini adalah untuk mencari perlakuan asam terbaik pada proses demineralisasi dan waktu terbaik pada proses ekstraksi menggunakan aquades berdasarkan rendemen tertinggi. Selanjutnya menguji sifat fisikokimia gelatin dari rendemen tertinggi. Pelarut asam yang digunakan adalah asam klorida $(\mathrm{HCl})$, asam sulfat $\left(\mathrm{H}_{2} \mathrm{SO}_{4}\right)$, dan asam asetat $\left(\mathrm{CH}_{3} \mathrm{COOH}\right)$ dengan konsentrasi masing-masing 2, 4 dan $6 \% \mathrm{v} / \mathrm{v}$. Variasi waktu ekstraksi yaitu 2, 4 dan 6 jam. Sifat fisikokimia gelatin yang diuji meliputi uji kualitatif dan uji kuantitatif. Uji kualitatif gelatin terdiri atas uji kualitatif protein, uji organoleptik (bentuk, warna, bau, kelarutan), dan penentuan gugus fungsi gelatin menggunakan Fourier Transform Infra-Red (FTIR). Sedangkan uji kuantitatif gelatin terdiri atas $\mathrm{pH}$, proksimat, titik leleh, viskositas, titik isoelektrik, dan masa molekul relatif rata-rata.

\section{Metode \\ 2.1. Bahan}

Bahan-bahan yang digunakan pada penelitian ini terdiri dari limbah tulang ikan yang berasal dari pasar Bogor, asam asetat $\left(\mathrm{CH}_{3} \mathrm{COOH}\right)$, asam sulfat $\left(\mathrm{H}_{2} \mathrm{SO}_{4}\right)$, dan asam klorida $(\mathrm{HCl})$, gelatin isolasi tulang ikan tenggiri dan gelatin isolasi tulang ikan gurame yang diisolasi menggunakan perlakuan terbaik pada isolasi tulang ikan kembung, gelatin komersial dari bahan baku sapi dan babi yang diperoleh dari LPPOM MUI Bogor, aquades, ninhydrin $0,1 \%, \mathrm{CuSO}_{4} \quad 0,1 \%, \mathrm{PbS} 1 \%$, $\mathrm{K}_{2} \mathrm{Cr}_{2} \mathrm{O}_{7} 0,2 \mathrm{M}, \mathrm{HCl} 3 \mathrm{~N}, \mathrm{NaOH} 10 \%$, selenium, $\mathrm{H}_{2} \mathrm{SO}_{4}$ pekat, indikator Brom Cresol Green-Methyl Red (BCGMR), $\mathrm{NaOH} 40 \%, \mathrm{HCl} 0,1 \mathrm{~N}, \mathrm{H}_{3} \mathrm{BO}_{3} 2 \%$, dan $\mathrm{KBr}$. Bahan-bahan kimia yang digunakan merupakan analytical grade dari Merck Co.

\subsection{Alat}

Alat-alat yang digunakan pada penelitian ini terdiri dari neraca analitik Gram FV 220, oven vakum Gallenkamp, hotplate dan magnetic stirrer Thermo Scientific, sikat, seperangkat alat Kjehdal, seperangkat alat refluks, loyang alumunium, $\mathrm{pH}$ meter Ohaus Starter 3100, tanur Muffle Furnace, Fourier Transform Infrared (FTIR) Spektrofotometer merk IRPrestige-21 Shimadzu, Brookfield Viscometer DV-II+ Pro, Turbidimeter merk HI98713 Precision ISO Turbidity Portable Meter, viskometer Ostwald, kain saring, desikator, stopwatch, botol semprot, dan peralatan gelas seperti erlenmeyer, piala gelas dan sebagainya dari IWAKI. 


\subsection{Posedur penelitian}

Populasi pada penelitian yang dilakukan adalah limbah tulang ikan kembung sebanyak $1 \mathrm{~kg}$ yang diambil dari limbah tulang ikan yang terdapat di pasar Bogor. Sampel merupakan bagian dari populasi yaitu cuplikan dari limbah tulang ikan kembung yang sudah didemineralisasi menggunakan berbagai jenis larutan asam dengan variasi konsentrasi, serta lamanya waktu ekstraksi menggunakan aquades. Variabel terikat pada penelitian yang dilakukan adalah kualitas gelatin yang diperoleh sesuai standar yang berlaku. Variabel bebas dalam penelitian yang dilakukan adalah jenis asam, konsentrasi asam, serta lamanya waktu ekstraksi.

Variabel terkendali adalah variabel yang dikendalikan. Variabel terkendali dalam penelitian yang dilakukan ini adalah suhu pada saat degreasing sebesar $80{ }^{\circ} \mathrm{C}$, suhu hotplate pada saat pemekatan $80{ }^{\circ} \mathrm{C}$, dan suhu oven pada saat tahap pengeringan sebesar $55^{\circ} \mathrm{C}$, perbandingan antara bobot tulang ikan (gram) dengan volume larutan asam $(\mathrm{mL})$ masing-masing konsentrasi 2 , 4 , dan $6 \% \mathrm{v} / \mathrm{v}$ adalah $1: 4$ pada saat demineralisasi tulang ikan, serta perbandingan antara bobot ossein (gram) dengan akuades (mL) yaitu 1:3 pada saat ekstraksi. Setiap perlakuan dilakukan dua kali pengulangan (duplo). Untuk melihat pengaruh variasi perlakuan terhadap gelatin hasil isolasi dilakukan uji statistik yaitu two-way analysis of variance (ANOVA). Uji sifat fisikokimia dilakukan pada sampel gelatin hasil isolasi yang memiliki rendemen tertinggi.

\subsection{Isolasi gelatin dari limbah ikan kembung dengan metode asam (modifikasi metode Singkuku et al., 2017)}

Penelitian dimulai dengan melakukan degreasing, bertujuan menghilangkan lemak dan sisa-sisa daging yang masih melekat pada tulang. Degreasing dilakukan dengan perebusan pada suhu $80{ }^{\circ} \mathrm{C}$ selama 30 menit. Kemudian tulang ikan dibersihkan dengan sikat dan dikeringkan dalam oven pada suhu $50{ }^{\circ} \mathrm{C}$ selama 12 jam. Bahan baku tulang ikan kering dipotong dengan ukuran 1,5-2 cm. Setelah itu, dilakukan demineralisasi untuk menghilangkan komponen anorganik dari bahan baku, kemudian dilakukan ekstraksi.

Demineralisasi dilakukan dengan perendaman tulang ikan dalam larutan $\mathrm{CH}_{3} \mathrm{COOH}, \mathrm{H}_{2} \mathrm{SO}_{4}$, dan $\mathrm{HCl}$, dengan konsentrasi masing-masing 2, 4 dan $6 \% \mathrm{v} / \mathrm{v}$ selama 48 jam dengan perbandingan bobot tulang (gram) dan volume larutan asam $(\mathrm{mL})$ tiap konsentrasi yaitu 1:4. Larutan asam yang digunakan sebagai perendam diganti tiap 1 hari. Perendaman tersebut akan menghasilkan ossein. Selanjutnya ossein dicuci sampai $\mathrm{pH}$ netral dengan air mengalir. Kemudian diekstraksi dengan akuades pada suhu $80{ }^{\circ} \mathrm{C}$ selama 2, 4 dan 6 jam dengan perbandingan bobot ossein (gram) dan volume akuades $(\mathrm{mL})$ adalah $1: 3$. Hasil ekstraksi ini disaring dengan kain saring blacu dan ditempatkan ke dalam cawan, kemudian dipekatkan di atas hoplate suhu $80{ }^{\circ} \mathrm{C}$ selama \pm 12 jam dan dikeringkan di dalam oven suhu $\pm 55^{\circ} \mathrm{C}$ selama \pm 12 jam hingga terbentuk lembaran gelatin. Lembaran gelatin ini selanjutnya digiling sampai diperoleh tepung gelatin.

\subsection{Total rendemen (AOAC, 1995)}

Rendemen diperoleh dari perbandingan bobot kering tepung gelatin yang dihasilkan dengan bobot bahan segar (tulang yang telah dicuci bersih), dengan menggunakan rumus:

$$
\text { Rendemen }=\frac{\text { Bobot kering gelatin }}{\text { Bobot tulang segar }} \times 100 \%
$$

\subsection{Uji kualititatif protein (British Pharmacopoeia, 2016 and Farmakope Indonesia V, 2012)}

Uji kualitatif protein yang dilakukan meliputi uji Biuret, Uji Ninhydrin, Uji PbS, dan Uji kromat.

\subsection{Nilai pH (British Pharmacopoeia, 2016)}

Nilai $\mathrm{pH}$ gelatin diukur menggunakan $\mathrm{pH}$ meter yang dikalibrasi dan harus distandardisasi dengan larutan buffer $\mathrm{pH}$ 4, 7 dan 10 sebelum digunakan.

\subsection{Uji proksimat (AOAC, 1995)}

Kadar air dan kadar abu dilakukan menggunakan metode gravimetri, kadar protein menggunakan metode Kjedhal, kadar lemak menggunakan metode Soxhlet, dan kadar karbohidrat dengan metode by difference.

\subsection{Penentuan viskositas (modifikasi metode AOAC, 1995)}

Larutan gelatin dengan konsentrasi 6,67\% (b/b) yaitu $7 \mathrm{~g}$ gelatin ditambah $105 \mathrm{~mL}$ aquades, kemudian viskositas larutan diukur dengan menggunakan alat Viscometer Brookfield. Pengukuran dilakukan pada suhu $60{ }^{\circ} \mathrm{C}$ dengan laju kecepatan $200 \quad \mathrm{rpm}$ menggunakan spindle LCP.

\subsection{Penentuan titik leleh (modifikasi metode Mahmuda et al., 2018)}

Sampel gelatin sebanyak $1 \mathrm{~g}$ dimasukkan ke dalam plastik sampel. Sampel tersebut didiamkan pada suhu ruang berkisar $25-32{ }^{\circ} \mathrm{C}$ selama 5 jam (09.00-14.00 WIB). Hasil titik leleh ditandai dengan menggumpalnya serbuk gelatin menjadi satu dalam wadah.

\subsection{Titik isoelektrik protein (modifikasi metode AOAC, 1995)}

Sampel gelatin sebanyak $0,2 \mathrm{~g}$ ditambah dengan 40 $\mathrm{mL}$ aquades, kisaran $\mathrm{pH}$ larutan 4,5-10,5. Pengadukan dilakukan selama 30 menit. Selanjutnya diakukan pengukuran dengan turbidimeter. Tingginya nilai NTU yang dihasilkan merupakan titik isoelektriknya.

\subsection{Analisis FTIR}

Sampel gelatin $1 \mathrm{mg}$ dicampur dengan $\mathrm{KBr} 10 \mathrm{mg}$ dan dibuat kepingan. Sampel dibaca menggunakan alat FTIR dengan bilangan gelombang $4500-500 \mathrm{~cm}^{-1}$. 


\subsection{Penentuan massa molekul relatif rata-rata gelatin (modifikasi metode Suwardi et al., 2010)}

Serbuk gelatin $0,3 \mathrm{~g}$ dilarutkan dalam $10 \mathrm{~mL}$ pelarut air (akuades) pada suhu $55{ }^{\circ} \mathrm{C}$. Larutan dimasukkan ke dalam viskometer Ostwald. Waktu alir larutan dan pelarut diukur dengan menggunakan stopwatch sebanyak tiga kali. Data waktu alir digunakan untuk menghitung viskositas relatif, viskositas tereduksi dan viskositas intrinsik. Perlakuan di atas diulangi untuk variasi bobot gelatin 0,$35 ; 0,40 ; 0,45$; dan 0,50 g. Massa molekul relatif rata-rata viskositas gelatin ditentukan dari viskositas intrinsik menggunakan persamaan MarkHouwink-Sakurada:

$[\eta]=\mathrm{K} \cdot \mathrm{Mv}^{\alpha}$

$\mathrm{K}=1,66 \times 10^{-5}$ dan $\alpha=0,885$ untuk polimer gelatin sapi dalam pelarut air pada temperatur ruang.

\section{Hasil dan pembahasan}

\subsection{Isolasi gelatin}

Prinsip kerja dari proses asam ini adalah asam mampu mengubah serat kolagen dengan struktur triple helix menjadi rantai tunggal hanya memerlukan waktu relatif singkat. Ion $\mathrm{H}^{+}$dari larutan asam akan berinteraksi dengan kolagen. Sebagian ikatan hidrogen dalam tropokolagen serta ikatan-ikatan silang yang menghubungkan tropokolagen satu dengan tropokolagen lainnya, dihidrolisis menghasilkan rantai-rantai tropokolagen yang mulai kehilangan struktur triple helix (Martianingsih and Atmaja, 2010). Hidrolisis yang terjadi pada kolagen umumnya merupakan hidrolisis dari gugus amida. Gugus amida adalah penyusun ikatan peptida yang terdapat dalam protein kolagen yang terkandung dalam sampel tulang ikan. Protein yang diberi perlakuan pemanasan atau pemberian asam akan memutus ikatan peptida yang terbentuk di dalamnya.

Gambar 1 menjelaskan tentang mekanisme reaksi hidrolisis gugus amida yaitu dimulai dari proton $\left(\mathrm{H}^{+}\right)$ pada asam menyerang atom oksigen pada gugus amida dibantu oleh gugus $\mathrm{H}_{2} \mathrm{O}$ pada larutan asam menyerang atom $\mathrm{C}$ gugus amida (intermediet I) dilanjutkan penyerangan pada atom $\mathrm{N}$ pada $\mathrm{NH}_{2}$ (intermediet II). Kemudian mulai terjadi pemutusan gugus $\mathrm{NH}_{3}$ (intermediet III) menghasilkan gugus karboksilat dan amonia. Gugus karboksilat ini yang menyebabkan senyawa yang dihasilkan dari proses isolasi yaitu gelatin menjadi mudah terekstrak dengan air. Hal ini dikarenakan sifat dari gugus asam karboksilat yang dapat membentuk ikatan hidrogen dengan molekul air, sehingga menyebabkannya mudah larut dalam air (Hart, 2003).

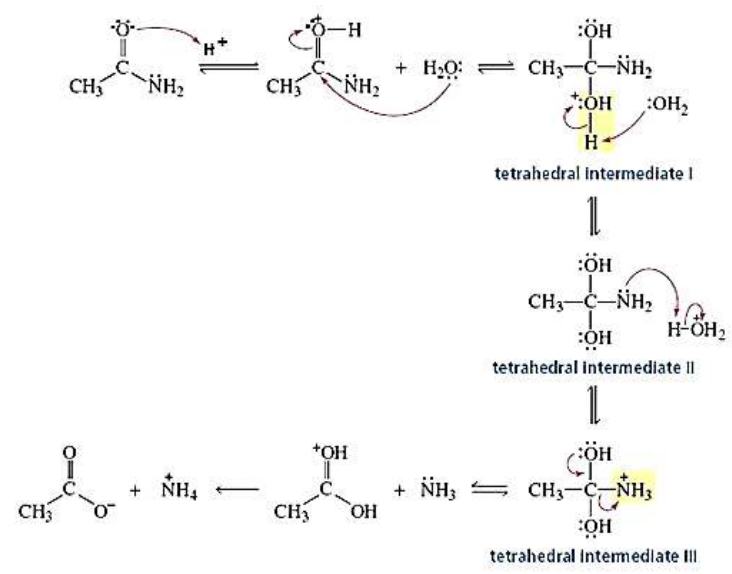

Gambar 1. Reaksi hidrolisis amida

(Sumber: Hart, 2003)

Pelarut asam yang digunakan dalam isolasi gelatin tipe A dari tulang ikan kembung ini, terdiri dari asam klorida $(\mathrm{HCl})$, asam sulfat $\left(\mathrm{H}_{2} \mathrm{SO}_{4}\right)$, dan asam asetat $\left(\mathrm{CH}_{3} \mathrm{COOH}\right)$ dengan konsentrasi masing-masing 2, 4 dan $6 \%$. Berdasarkan penelitian diperoleh rendemen yang bervariasi pada setiap pelarut asam yang digunakan dalam isolasi gelatin dari limbah tulang ikan kembung (Gambar 2).

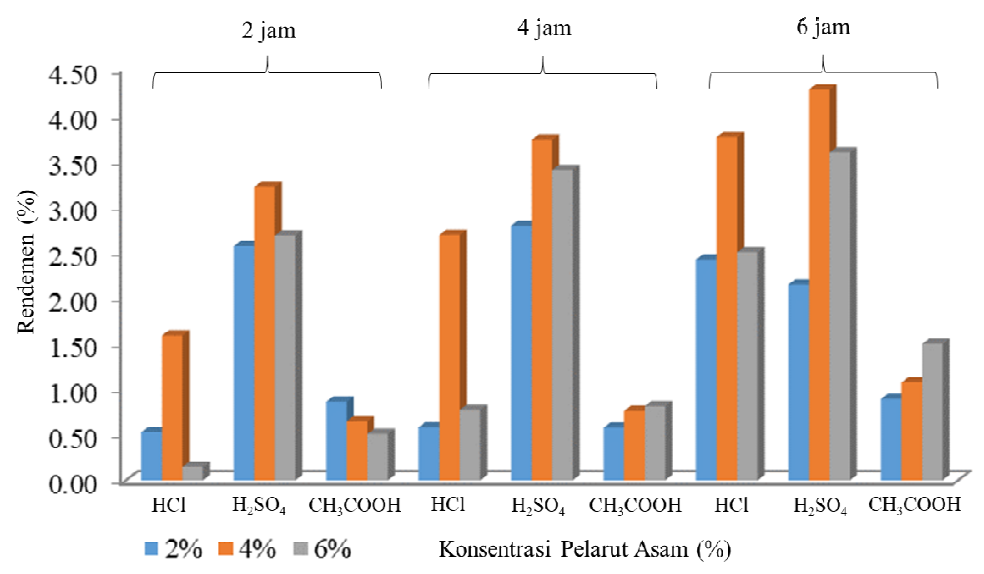

Gambar 2. Rendemen hasil isolasi gelatin dengan berbagai pelarut asam dan lamanya waktu ekstraksi

Demineralisasi dikenal sebagai proses perendaman dalam larutan asam yang mengakibatkan terjadinya swelling (penggembungan), yang dapat menghilangkan garam kalsium dan garam-garam lainnya serta 
membuang material-material yang tidak diinginkan, seperti lemak dan protein non-kolagen pada tulang dengan kehilangan kolagen yang minimum sehingga diperoleh ossein (tulang lumer) (Suwardi et al., 2010).

Perendaman dengan $\mathrm{H}_{2} \mathrm{SO}_{4}$ terlihat memiliki nilai rendemen tertinggi yaitu sebesar $4,27 \%$ pada konsentrasi $4 \%$ dalam waktu ektraksi dengan air selama 6 jam (Gambar 2). Kecenderungan tingginya hasil rendemen pada perendaman dengan $\mathrm{H}_{2} \mathrm{SO}_{4} 4 \%$, dikarenakan jenis asam yang digunakan ini memiliki banyak ion $\mathrm{H}^{+}$yang akan berinteraksi dengan struktur tropokolagen. Satu mol $\mathrm{H}_{2} \mathrm{SO}_{4}$ dilarutkan dalam air menghasilkan asam yang lebih pekat ( $\mathrm{pH}$ lebih rendah) daripada $1 \mathrm{~mol} \mathrm{HCl}$, karena asam sulfat memiliki 2 ion $\mathrm{H}^{+}$yang dapat terdisosiasi dalam air. Namun, kekuatan asam $\mathrm{H}_{2} \mathrm{SO}_{4}$ cenderung lebih rendah dibandingkan dengan $\mathrm{HCl}$. Hal ini dapat terlihat dari nilai $\mathrm{pKa} \mathrm{HCl}$ yaitu -6 lebih kecil daripada $\mathrm{pKa} \mathrm{H}_{2} \mathrm{SO}_{4}$ yaitu -3 .

Berdasarkan penelitian, penambahan asam-asam tersebut dalam waktu yang bersamaan menghasilkan adanya buih gas $\mathrm{H}_{2}$, perubahan warna tulang, dan melunaknya tulang menandakan adanya reaksi antara asam dengan senyawa-senyawa yang terkandung dalam tulang ikan. Pengamatan secara visual, terlihat bahwa asam klorida lebih cepat menghasilkan buih dan tulang yang lebih lunak dibandingkan dengan $\mathrm{H}_{2} \mathrm{SO}_{4}$ atau $\mathrm{CH}_{3} \mathrm{COOH}$, hal ini sesuai dengan teori bahwa $\mathrm{HCl}$ yang memiliki molekul nonsterik dengan perbedaan keelektronegatifan antar atom $\mathrm{H}$ dan $\mathrm{Cl}$ ini lebih bersifat reaktif (Yenti et al., 2015).

Selain timbulnya buih, terdapat perubahan lain setelah dilakukan demineralisasi atau perendaman asam yaitu terjadinya perubahan warna tulang (Gambar 3). Perendaman dengan $\mathrm{H}_{2} \mathrm{SO}_{4}$ menghasilkan tulang berwarna putih dibandingkan pada jenis asam lainnya (Gambar 3). Hal ini dapat dikarenakan banyaknya ikatan hidrogen yang terputus pada senyawa yang terdapat pada tulang seperti kolagen, sehingga menyebabkan tulang menjadi berwarna putih (Adiningsih and Purwanti, 2016).

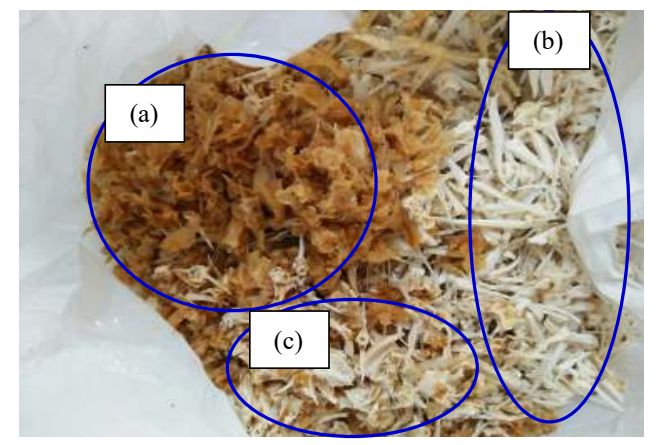

Gambar 3. Sisa tulang setelah proses demineralisasi dengan larutan (a) $\mathrm{HCl}$, (b) $\mathrm{H}_{2} \mathrm{SO}_{4}$, dan (c) $\mathrm{CH}_{3} \mathrm{COOH}$.

Isolasi gelatin dari tulang ikan kembung menggunakan proses asam ini meliputi beberapa tahap diantaranya pembersihan limbah tulang, degreasing, reduksi ukuran tulang, demineralisasi, ekstraksi, pemekatan, dan pengeringan. Pembersihan limbah tulang ikan kembung dilakukan dengan cara pencucian menggunakan air mengalir. Hal ini bertujuan menghilangkan bau amis yang berlebih dari limbah tulang ikan kembung, dan kotoran-kotoran lain yang mungkin mengandung deposit-deposit lemak yang cukup tinggi.

Tahap selanjutnya dilakukan proses degreasing pada limbah tulang ikan kembung. Proses degreasing bertujuan menghilangkan lemak dan sisa-sisa daging yang masih melekat pada jaringan tulang. Pada proses degreasing ini dilakukan dengan perebusan pada suhu $80{ }^{0} \mathrm{C}$ selama 30 menit. Suhu $80{ }^{0} \mathrm{C}$ ini dipilih sebagai suhu degreasing, karena penghilangan lemak pada tulang ikan kembung efektif dilakukan pada suhu antara titik cair lemak dan suhu koagulasi albumin tulang yaitu antara 32-80 ${ }^{\circ} \mathrm{C}$, sehingga dihasilkan kelarutan lemak yang optimum (Nurilmala et al., 2017). Suhu $80{ }^{\circ} \mathrm{C}$ dengan waktu 30 menit ini dipilih karena merupakan suhu kelarutan lemak optimum untuk penghilangan lemak dari tulang ikan, dalam hal ini adalah tulang ikan kembung (Singkuku et al., 2017). Apabila waktu atau suhu melebihi batas tersebut dikhawatirkan karena lemak yang terkandung dalam tulang telah terekstrak habis, maka perebusan akan menguraikan protein yang terkandung sehingga protein menjadi rusak terlebih dahulu akibat perebusan. Hal ini yang akan menyebabkan hasil untuk isolasi gelatin akan memiliki rendemen yang kecil, atau bahkan bukan menghasilkan gelatin namun protein yang lebih sederhana lagi dbandingkan gelatin.

Pembersihan tulang dari daging yang masih menempel dilanjutkan dengan cara menyikat tulang, sehingga tulang ikan kembung yang akan diisolasi adalah murni tulang. Hal ini bertujuan agar daging tidak mengganggu proses isolasi gelatin, adanya daging dapat memberikan penurunan rendemen karena dikhawatirkan ketika proses ekstraksi gelatin yang terekstrak bukan gelatin dari tulang melainkan senyawa lain yang terkandung dalam daging. Selanjutnya tulangikan kembung yang telah bersih dimasukkan ke dalam oven pada suhu $50{ }^{\circ} \mathrm{C}$ untuk menghilangkan kadar air yang terkandung dalam tulang, sehingga lebih mudah dilakukan pengecilan ukuran. Pengecilan ukuran tulang ikan kembung untuk memperluas permukaan tulang sehingga reaksi berlangsung lebih cepat dan sempurna (Wijaya et al., 2015).

\subsection{Analisis kualitatif gelatin hasil isolasi}

Berdasarkan hasil uji statistik, nilai signifikan yang diperoleh adalah $0,000(\mathrm{p} \leq 0,05)$ menunjukkan bahwa terdapat perbedaan yang signifikan dari nilai rendemen gelatin hasil isolasi dari setiap jenis asam, konsentrasi larutan dan lamanya waktu ekstraksi dengan aquades. Gelatin hasil isolasi dengan rendemen tertinggi yaitu pada perendaman dengan pelarut $\mathrm{H}_{2} \mathrm{SO}_{4} \quad 4 \%$ dengan ekstraksi air selama 6 jam, selanjutnya dilakukan analisis lanjutan untuk mengetahui kualitas gelatin tersebut. Analisis lanjutan yang dilakukan terbagi menjadi dua yaitu secara kualitatif dan secara kuantitatif. Analisis secara kualitatif yang dilakukan diantaranya terdiri dari uji organoleptik, uji kualitatif protein, dan penentuan gugus fungsi dengan FTIR. Hasil analisis kualitatif ini dapat dilihat pada Tabel 1. 
Berdasarkan Tabel 1, gelatin hasil isolasi tersebut memiliki hasil uji organoleptik meliputi bentuk, warna, dan bau sesuai dengan standar Farmakope V (Ditjen POM, 2012). Gelatin dibagi menjadi 2 kategori yaitu gelling grade dan non-gelling grade (British Pharmacopoeia, 2016). Gelatin dengan kategori gelling grade ini memiliki bentuk padat berwarna kuning atau coklat kekuningan, biasanya seperti lembaran tembus pandang, butiran atau bubuk sedangkan untuk gelatin dengan kategori non-gelling grade ini memiliki bentuk seperti butiran atau serbuk berwarna kuning atau putih. Sampel gelatin hasil isolasi dalam penelitian, apabila dilihat dari kategori yang telah disebutkan di atas maka gelatin tersebut termasuk kategori gelling grade.

Gelatin memiliki susunan asam amino yang hampir mirip dengan kolagen, terdiri dari glisin sebagai asam amino utama. Glisin merupakan 2/3 asam amino dari seluruh asam amino yang menyusun gelatin dan kolagen, sedangkan $1 / 3$ asam amino yang tersisa terdiri dari prolin dan hidroksiprolin (Singkuku et al., 2017).
Apabila dilihat dari susunannya, sampel gelatin akan menghasilkan uji positif pada setiap uji kualitatif protein kecuali uji $\mathrm{PbS}$. Hal ini dikarenakan, pada ketiga asam amino tersebut tidak mengandung adanya unsur $\mathrm{S}$ di dalam strukturnya, sehingga hasil uji $\mathrm{PbS}$ ini akan menunjukkan hasil yang negatif (Indrawan et al., 2016).

Analisis kualitatif yang terakhir adalah menggunakan FTIR untuk melihat gugus fungsi yang ada dalam sampel gelatin tulang ikan kembung hasil isolasi dengan perlakuan terbaik, gelatin tulang ikan gurame, gelatin tulang ikan tenggiri, standar gelatin, gelatin komersial sapi, dan gelatin komersial babi sebagai pembanding. Gelatin seperti umumnya protein memiliki struktur yang terdiri dari gugus hiroksil $(-\mathrm{OH})$, gugus karbonil $(\mathrm{C}=\mathrm{O})$, gugus amina $(\mathrm{N}-\mathrm{H})$, gugus alkana (C-H), dan gugus nitril (C-N). Bilangan gelombang yang menunjukkan gugus-gugus fungsi tersebut muncul pada spektra data FTIR hasil pengujian (Tabel 2).

Tabel 1.

Hasil analisis secara kualitatif gelatin tulang ikan kembung dengan perlakuan terbaik

\begin{tabular}{lll}
\hline Uji & Hasil & Farmakope V (Ditjen POM, 2012) \\
\hline Bentuk & Lembaran film, serbuk kasar & Lembaran, kepingan, serbuk kasar-halus \\
Warna & Kuning kecoklatan & Kuning lemah-coklat terang \\
Bau & Bau Ikan lemah & Kaldu lemah \\
Kelarutan & Larut dalam air panas, gliseril:air panas (1:1), & Larut dalam air panas, gliseril:air panas \\
& $\mathrm{CH}_{3} \mathrm{COOH}$ 6N; Tidak larut dalam air dingin dan & $(1: 1), \mathrm{CH}_{3} \mathrm{COOH}$ 6N; Tidak larut dalam \\
& pelarut organik (eter, kloroform) & air dingin dan pelarut organik (eter, etanol, \\
& & minyak lemak, kloroform) \\
Uji Biuret & Positif (Ungu) & - \\
Uji Ninhydrin & Tidak ada perubahan warna (Kuning) & - \\
Uji PbS & Negatif (Tidak ada endapan) & - \\
Uji Kromat & Positif (Endapan Kuning) & - \\
Uji FTIR & Sesuai dengan komersial & - \\
\hline
\end{tabular}

Tabel 2.

Bilangan gelombang dari gelatin hasil isolasi dengan perlakuan terbaik dan gelatin komersial

\begin{tabular}{lllll}
\hline Gelatin & $\begin{array}{l}\text { Daerah OH dan NH } \\
\left(3600-3000 \mathrm{~cm}^{-1}\right)\end{array}$ & $\begin{array}{l}\text { Daerah CH } \\
\left(3000-2850 \mathrm{~cm}^{-1}\right)\end{array}$ & $\begin{array}{l}\text { Daerah C=O } \\
\left(1800-1600 \mathrm{~cm}^{-1}\right)\end{array}$ & $\begin{array}{l}\text { Daerah C-N } \\
\left(1400-1100 \mathrm{~cm}^{-1}\right)\end{array}$ \\
\hline Kembung & 3246,34 & 2854,77 & 1623,17 & 1452,46 \\
Gurame & 3246,34 & 2853,81 & 1622,2 & 1427,39 \\
Tenggiri & 3213,55 & 2854,77 & 1625,1 & 1342,51 \\
Komersial Sapi & 3135,42 & 2876,95 & 1638,6 & 1325,15 \\
Komersial Babi & 3472,02 & 2852,84 & 1618,35 & 1427,39 \\
\hline
\end{tabular}

Dari Spektra FTIR pada masing-masing sampel uji (Gambar 4), menunjukkan adanya vibrasi stretching gugus fungsi $\mathrm{OH}$ pada bilangan gelombang sekitar $3500-3100 \mathrm{~cm}^{-1}$ yang memberikan puncak lebar. Puncak $\mathrm{N}-\mathrm{H}$ pada spektrum tidak ditemukan hal ini dikarenakan daerah bilangan gelombangnya sama dengan $\mathrm{OH}$, sehingga puncak yang dihasilkan tertutupi oleh puncak $\mathrm{OH}$ (Panji, 2012). Bilangan gelombang $\mathrm{C}=\mathrm{O}$ yang spesifik untuk amida adalah $1690-1630 \mathrm{~cm}^{-1}$, tetapi terjadi pergeseran bilangan gelombang pada gugus $\mathrm{C}=\mathrm{O}$ dari sampel dan standar gelatin yaitu bilangan gelombang yang dihasilkan berada pada 1640-1610 $\mathrm{cm}^{-1}$. Hal ini dapat dikarenakan pencampuran $\mathrm{KBr}$ dengan sampel gelatin tidak tercampur secara homogen, sehingga terjadinya pergeseran gugus fungsi yang dapat menyebabkan pembacaan gugus fungsi menjadi tidak tepat. Namun, pada bilangan gelombang yang dihasilkan tersebut masih masuk dalam rentang adanya gugus $\mathrm{C}=\mathrm{O}$ (1800-1600 $\mathrm{cm}^{-1}$ ) pada sampel uji.

Selain itu, bilangan gelombang untuk C-H dan C-N berturut-turut muncul pada daerah $2850-2880 \mathrm{~cm}^{-1}$ dan 1410-1310 $\mathrm{cm}^{-1}$ (Mahmuda et al., 2018). Gugus $\mathrm{OH}$ yang ditunjukkan oleh spektrum FTIR menandakan adanya asam amino hidroksiprolin yang merupakan penyusun utama dari gelatin, dan adanya senyawa $\mathrm{OH}$ dari air yang digunakan untuk mengekstraksi gelatin. Spektrum senyawa yang diperoleh pada penelitian ini menunjukkan gugus fungsi yang sama dengan kedua 
gelatin komersial tersebut, sehingga dapat disimpulkan bahwa senyawa yang diperoleh dari penelitian ini adalah gelatin.

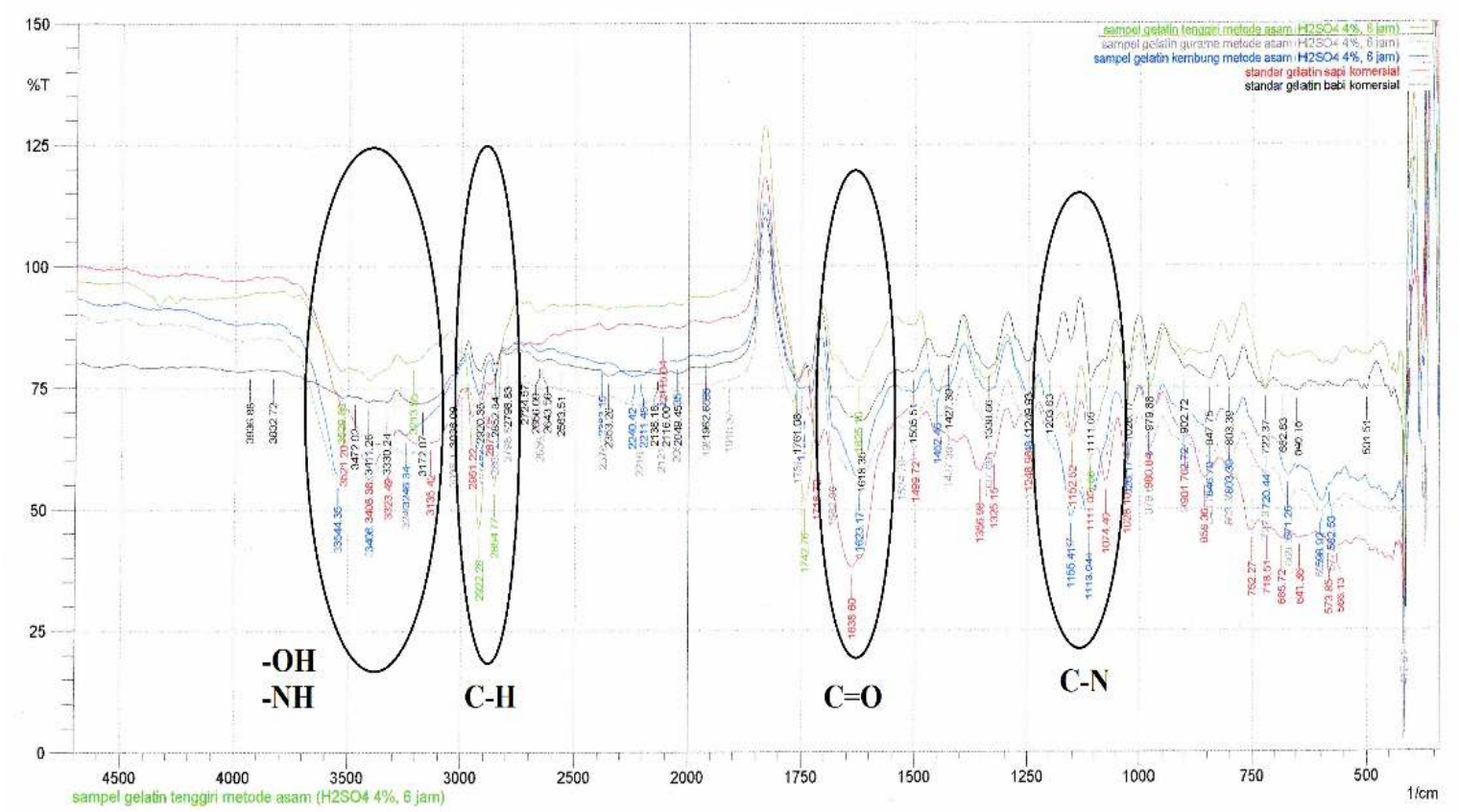

Gambar 4. Spektra FTIR dari gelatin hasil isolasi ikan kembung, gelatin gurame, gelatin tenggiri, standar gelatin komersial babi, dan standar gelatin komersial sapi

Tabel 3.

Hasil analisis kuantitatif gelatin tulang ikan kembung

\begin{tabular}{lllll}
\hline Uji & Hasil & $\begin{array}{l}\text { European Pharmacopoeia } \\
(2014)\end{array}$ & GMIA (2012) & $\begin{array}{l}\text { British Standar: } \\
757(1975)\end{array}$ \\
\hline Derajat keasaman (pH) & 4,0 & $3,8-7,6$ & $3,8-5,5$ & $4,5-6,5$ \\
Kadar Air (\%) & 9,30 & $<15$ & $<10,5$ & - \\
Kadar Abu (\%) & 23,85 & - & $0,3-2$ & - \\
Kadar Protein (\%) & 58,37 & - & $>90$ & - \\
Kadar Lemak (\%) & 0,86 & - & $<5$ & - \\
Kadar Karbohidrat (\%) & 7,63 & - & 0 & - \\
Viskositas (cPs) & 2,80 & - & $15-75 \mathrm{mps}$ atau & $15-70 \mathrm{mps}$ atau \\
& & & $1,5-7,5 \mathrm{cPs}$ & $1,5-7 \mathrm{cPs}$ \\
Titik Leleh $\left({ }^{0} \mathrm{C}\right)$ & $28-31,2$ & - & $<35$ & - \\
Titik Isoelektrik & 9,0 & $6-9,5$ & $7-9$ & - \\
Bobot Molekul (g/mol) & $38.390,9$ & - & - & - \\
\hline
\end{tabular}

Keterangan: GMIA (Gelatin Manufacturers Institute of America).

\subsection{Analisis kuantitatif gelatin hasil isolasi}

Analisis kuantitatif yang dilakukan terdiri dari derajat keasaman $(\mathrm{pH})$, analisis proksimat, titik leleh, titik isoelektrik, viskositas, dan penentuan bobot molekul. Hasil analisis kuantitatif dari gelatin tulang ikan kembung tersebut dengan perendaman $\mathrm{H}_{2} \mathrm{SO}_{4} 4 \%$ selama 6 jam dapat dilihat pada Tabel 3 .

Kandungan air dalam gelatin dapat mempengaruhi penampakan, tekstur, cita rasa serta mutu bahan pangan. Kadar air gelatin akan berpengaruh terhadap daya simpan, karena erat kaitannya dengan aktivitas metabolisme yang terjadi selama gelatin tersebut disimpan seperti aktivitas enzim, aktivitas mikroba dan aktivitas kimiawi, yaitu terjadinya ketengikan dan reaksi-reaksi non enzimatik, sehingga menimbulkan perubahan sifat-sifat kualitas dari gelatin dan nilai mutunya (Darwin et al., 2018).

Berdasarkan penelitian diperoleh kadar air dari gelatin tulang ikan kembung yang diperoleh adalah sebesar 9,30\%. Hasil tersebut masih masuk ke dalam syarat yang telah ditetapkan oleh SNI 06-3735-1995 (BSN, 1995) maupun European Pharmacopoeia (European Pharmacopoeia Commission, 2014), yaitu maksimal $16 \%$ dan $15 \%$ untuk gelatin.

Nilai kadar abu suatu bahan pangan menunjukkan besarnya jumlah mineral yang terkandung dalam suatu bahan pangan tersebut. Semakin rendah kadar abu suatu bahan, maka semakin tinggi kemurniannya. Berdasarkan penelitian diperoleh kadar abu dari sampel gelatin tulang 
ikan kembung sebesar 23,85\%. Nilai kadar abu tersebut terbilang tinggi, melebihi syarat yang telah ditetapkan oleh GMIA (2012) dan Famakope Indonesia V (Ditjen POM, 2012) yaitu sebesar $<2 \%$. Tingginya kadar abu gelatin tulang ikan kembung kemungkinan disebabkan oleh keberadaan mineral-mineral yang masih terikat pada kolagen akibat proses demineralisasi yang tidak sempurna (Panjaitan, 2016). Menurut Singkuku et al. (2017), seharusnya kandungan protein dalam sampel gelatin memiliki kadar yang tinggi dari kadar lainnya, seperti yang telah disebutkan oleh GMIA (2012) bahwa kandungan protein yang seharusnya terkandung dalam gelatin adalah sebesar $>90 \%$.

Berdasarkan hasil penelitian diperoleh 58,37\%. Hasil kadar protein dalam sampel gelatin yang rendah ini, dapat disebabkan oleh beberapa faktor diantaranya suhu ekstraksi yang tinggi menyebabkan adanya hidrolisis lanjutan, sehingga protein yang terkandung dalam sampel gelatin terurai menjadi unsur yang lebih sederhana seperti unsur pembentuknya yaitu $\mathrm{C}, \mathrm{N}, \mathrm{O}$, dan H (Yenti et al., 2015).

Penentuan selanjutnya adalah kadar lemak, karena lemak berpengaruh terhadap perubahan mutu gelatin selama penyimpanan. Kerusakan lemak yang utama diakibatkan oleh proses oksidasi, sehingga timbul bau dan rasa tengik disebut dengan proses ketengikan. Lemak berhubungan dengan mutu karena kerusakan lemak dapat menurunkan nilai gizi, serta menyebabkan penyimpangan rasa dan bau (Pertiwi et al., 2018).

Berdasarkan penelitian diperoleh hasil pengukuran kadar lemak gelatin tulang ikan kembung sebesar $0,86 \%$. Nilai kadar lemak ini masuk dalam standar yang telah ditetapkan oleh GMIA (2012), sebesar $<5 \%$ dari total berat gelatin. Hasil ini menunjukkan bahwa perlakuan selama proses pembuatan gelatin baik pada tahap degreasing hingga pada tahap penyaringan filtrat hasil ekstraksi, yang sudah cukup optimal. Apabila hasil kadar lemak dalam sampel gelatin tulang ikan kembung ini tinggi, maka perlu ada perlakuan khusus yang dilakukan untuk menghilangkan lemak pada tulang ikan kembung dengan melakukan perlakuan dengan peredaman dalam larutan asam dengan suhu dan waktu yang optimum pada tahap preparasi awal (Wijaya et al., 2015).

Selain kadar lemak, ditentukan pula kadar karbohidrat bertujuan untuk melihat kualitas gelatin yang dihasilkan. Berdasarkan penelitian diperoleh kadar karbohidrat sebesar 7,63\%, nilai tersebut melebihi syarat yang telah ditentukan oleh GMIA (2012) yaitu sebesar $0 \%$.

Titik isoelektrik protein menunjukkan kelarutan protein yang rendah sehingga, terjadi penggumpalan atau pengendapan protein. Titik isoelektrik ini ditentukan dengan menggunakan turbidimeter. Prinsip dari turbidimeter adalah sinar yang datang mengenai suatu partikel ada yang diteruskan dan ada yang dipantulkan, maka sinar yang diteruskan digunakan sebagai dasar pengukuran. Titik isoelektrik protein dapat bervariasi tergantung jumlah gugus karboksil amida pada gelatin. Apabila titik isoelektrik tinggi $(9,4)$, maka tidak ada modifikasi terhadap gugus amida dan apabila titik isoelektrik $(4,8)$, maka $90-95 \%$ protein dari gelatin merupakan gugus karboksil (Trilaksani et al., 2012).

Berdasarkan penelitian titik isoelektrik pada gelatin tulang ikan kembung adalah $\mathrm{pH} 9$ dengan nilai kekeruhan sebesar 180 NTU (Tabel 4). Titik isoelektrik 9 pada sampel gelatin menunjukkan bahwa gugus asam amino yang terkandung dalam penelitian ini memiliki perubahan pada asam karboksilat yang berperan aktif di dalamnya (Trilaksani et al., 2012).

Tabel 4.

Hasil titik isoeletrik sampel gelatin tulang ikan kembung hasil isolasi

\begin{tabular}{lllllllll}
\hline $\mathrm{pH}$ & 4 & 5 & 6 & 7 & 8 & 9 & 10 & 11 \\
\hline $\mathrm{NTU}$ & 27,3 & 57,8 & 72,3 & 136 & 158 & 180 & 131 & 118 \\
\hline
\end{tabular}

Titik leleh adalah suhu ketika gelatin yang telah membentuk gel mencair ketika dipanaskan (Trilaksani et al., 2012). Titik leleh pada penelitian ini dilakukan secara penglihatan fisik, sehingga hasil yang diperoleh dalam bentuk nilai dengan rentang tertentu. Berdasarkan penelitian diperoleh titik leleh gelatin dari bahan dasar tulang ikan kembung mempunyai nilai dengan rentang 28-31,2 ${ }^{\circ} \mathrm{C}$. Hal ini masih memenuhi standar GMIA (2012) yaitu $<35{ }^{\circ} \mathrm{C}$. Titik leleh dari gelatin memberikan sifat khas yang paling disukai oleh hampir seluruh industri makanan maupun farmasi yaitu melting in the mouth (meleleh dalam mulut), oleh sebab itu gelatin disebut miracle food (Rachmania et al., 2013).

Parameter lainnya yang juga penting dan menjadi standar penentu kualitas gelatin adalah nilai viskositas. Viskositas dapat dinyatakan sebagai tahanan aliran fluida yang merupakan gesekan antara molekul-molekul cairan satu dengan yang lain. Makin kental suatu cairan makin besar pula kekuatan yang diperlukan untuk digunakan supaya cairan tersebut dapat mengalir dengan laju tertentu (Pertiwi et al., 2018). Berdasarkan penelitian hasil viskositas gelatin sebesar 2,80 mPas setara dengan 2,80 cPs. Hasil viskositas dapat diterima sebagai nilai yang akurat apabila hasil persentase keakuratannya melebihi 55\%. Hasil pengujian diperoleh nilai viskositas gelatin tulang ikan kembung yaitu 2,8 cPs. Viskositas gelatin ini memenuhi rentang yang dipersyaratkan oleh GMIA (2012) yaitu 1,5-7,5 cPs dan British Standar (1975) yaitu 1,5-7 cPs. Namun, nilai viskositas tersebut masih cukup rendah untuk pembuatan kapsul keras, kapsul lunak, dan industri lainnya yang berskala besar, lebih tepat digunakan untuk bahan pangan (Simpen, 2016).

Penentuan bobot molekul relatif dari gelatin tulang ikan kembung menggunakan viscometer Ostwald. Pengukuran viskositas pada viskometer Ostwald dilakukan dengan menentukan waktu yang dibutuhkan oleh sejumlah volume larutan untuk mengalir diantara dua tanda kalibrasi. Penentuan besarnya viskositas larutan gelatin ini, digunakan sebuah pelarut berupa air 
(aquades). Pelarut ini digunakan karena dapat melarutkan gelatin dan nilai tetapan Mark-HouwinkSakurada (K dan $\alpha$ ) telah diketahui sesuai dengan handbook data polimer. Waktu alir larutan gelatin dibandingkan terhadap waktu alir pelarut untuk mendapatkan nilai viskositas spesifik ( $\eta \mathrm{sp})$. Nilai viskositas tereduksi $(\eta \mathrm{sp} / \mathrm{c})$ dialurkan terhadap konsentrasi (c) untuk memperoleh nilai viskositas intrinsik, $(\eta)$, yang merupakan intersep grafik (Gambar $5)$.

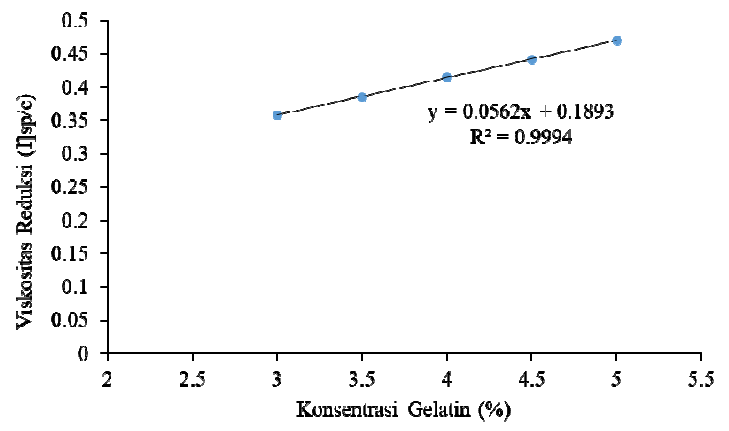

Gambar 5. Grafik hubungan antara viskositas reduksi (П $\mathrm{sp} / \mathrm{c})$ dengan konsentrasi gelatin

Nilai K sebesar $1,66 \times 10^{-5}$ dan $\alpha$ sebesar 0,885 untuk polimer gelatin dalam pelarut air pada suhu ruang. Konstanta $\mathrm{K}$ dan $\alpha$ yang digunakan ialah dari konstanta gelatin pada kulit anak sapi. Hal ini dilakukan karena harga $\mathrm{K}$ dan $\alpha$ gelatin dari tulang dan kulit ikan tidak ditemukan (Suwardi et al., 2010). Berdasarkan penelitian diperoleh bobot molekul relatif dari gelatin tulang ikan kembung hasil isolasi adalah sebesar $38.390,9 \mathrm{~g} / \mathrm{mol}$. Hasil tersebut masih masuk dalam standar yang telah ditetapkan yaitu berkisar antara $20.000 \mathrm{~g} / \mathrm{mol}$ sampai $250.000 \mathrm{~g} / \mathrm{mol}$ (Suryani et al., 2009). Bobot molekul relatif gelatin dari tulang ikan kembung ini tidak cukup akurat dikarenakan penggunaan nilai $\mathrm{K}$ dan $\alpha$ yang digunakan bukan untuk gelatin ikan, sehingga perlu dilakukannya uji lanjutan untuk memperoleh hasil yang akurat.

\section{Kesimpulan}

Gelatin tulang ikan kembung dengan rendemen tertinggi diperoleh dari hasil perendaman dengan $\mathrm{H}_{2} \mathrm{SO}_{4}$ $4 \%$ pada proses demineralisasi dan lama ekstraksi dengan aquades 6 jam yaitu sebesar 4,27\%. Pengujian sifat fisikokimia dari gelatin hasil isolasi dengan perlakuan terbaik memiliki $\mathrm{pH} 4,0$, titik isoelektrik 9,0, titik leleh $28-31,2{ }^{\circ} \mathrm{C}$, viskositas $2,8 \mathrm{cPs}$. Kualitas gelatin hasil isolasi tersebut memiliki hasil analisis proksimat yang mencakup kadar air sebesar 9,30\%, kadar abu $23,85 \%$, kadar protein 58,37\%, kadar lemak 0,86\% dan kadar karbohidrat 7,63\%. Analisis FTIR dari gelatin yang dihasilkan menunjukkan gugus-gugus fungsi $\mathrm{O}-\mathrm{H}$, $\mathrm{C}-\mathrm{H}, \mathrm{C}-\mathrm{N}, \mathrm{C}=\mathrm{O}$, dan $\mathrm{N}-\mathrm{H}$ yang sama dengan gelatin komersial. Namun, parameter kadar abu dan kadar protein masih belum memenuhi persyaratan, sehingga diperlukan optimasi pada proses demineralisasi dan suhu ekstraksi aquades agar gelatin hasil isolasi memenuhi standar mutu yang dipersyaratkan.

\section{Daftar pustaka}

Adiningsih, Y., Purwanti, T., 2016. Karakterisasi mutu gelatin ikan tenggiri dengan perendaman menggunakan asam sitrat dan asam sulfat. J. Ris. Teknol. Ind. 9, 149-156. https://doi.org/10.26578/ jrti.v9i2.1713

Agustin, A.T., 2013. Gelatin ikan: sumber, komposisi kimia dan potensi pemanfaatannya. Media Teknol. Has. Perikan. 1, 44-46. https://doi.org/10.35800/mthp.1.2.2013.4167.

AOAC, 1995. Official methods of analysis of the association of official analytical chemist. Association of Official Analytical Chemist

Arief, J., 2016. Model rencana bisnis produksi gelatin dari limbah pengolahan ikan. J. Kurs 1, 51-74.

Arima, I.N., Fithriyah, N.H., 2015. Pengaruh waktu ekstraksi terhadap rendemen gelatin dari tulang ikan nila merah. J. Semin. Sains Dan Teknol. 1-6.

Arisanti, D., Angelia, I.O., Amiruddin, 2021. Pemanfaatan tepung tulang ikan untuk bidang pertanian oleh masyarakat desa tanjung keramat gorontalo. Pangabdhi 7, 48-50.

BPS, 2016. Data ekspor impor gelatin di Indonesia. Badan Pusat Statistik.

British Pharmacopoeia, 2016. British pharmacopoeia, Volume IB. Medicines and healthcare products regulatory agency (MHRA).

British Standard, 1975. British Standard 757: 1975. Sampling and testing of gelatin.

BSN, 1995. Standar Nasional Indonesia SNI 06-3735: 1995, Mutu dan cara uji gelatin. Badan Standarisasi Nasional.

Darwin, D., Ridhay, A., Hardi, J., 2018. Kajian ekstraksi gelatin dari tulang ikan mujair (Oreochromis mossambicus). Kovalen J. Ris. Kim. 4, 1-15. https://doi.org/10.22487/kovalen.2018.v4.i1.10177.

Ditjen POM, 2012. Farmakope Indonesia V. Departemen Kesehatan RI. Direktorat Jenderal Pengawas Obat dan Makanan.

European Pharmacopoeia Commission, 2014. Gelatin. European Pharmacopoeia. Vol. II B. Ed 8.0. Council of Europe, pp. 2323-2324.

Faridah, H.D., Susanti, T., 2018. Polysaccharide as gelatin subtitute material in halal drug delivery system. J. Halal Prod. Res. 1, 15-21. https://doi.org/10.20473/jhpr.vol.1-issue.2.15-21.

Fasya, A.G., Amalia, S., Imamudin, M., Putri Nugraha, R., Ni'mah, N., Yuliani, D., 2018. Optimasi produksi gelatin halal dari tulang ayam broiler (Gallus domesticus) dengan variasi lama perendaman dan konsentrasi asam klorida ( $\mathrm{HCl})$. Indones. J. Halal 1, 102. https://doi.org/10.14710/halal.v1i2.3665.

GMIA, 2012. Gelatin Manufacturers Institute of America, Gelatin Handbook. GMIA Inc.

Hart, H., Craine, L.E., Hart, D.J., 2003. Kimia organik. Achmadi S.S, penerjemah. Terjemahan dari: Organic Chemistry. Erlangga.

Hidayat, G., Nurcahya Dewi, E., Rianingsih, L., 2016. Characteristics of bone gelatin tilapia (Oreochromis niloticus) processed by using hydrolysis with phosphoric acid and papain enzyme. J. Pengolah. 
Has. Perikan. Indones. 19, 69-78. https://doi.org/10.17844/jphpi.2016.19.1.69.

Indrawan, M. R., Agustina, R., Rijai, L., 2016. Ekstraksi gelatin dari kaki ayam broiler melalui berbagai larutan asam dan basa dengan variasi lama perendaman. J. Trop. Pharm. Chem. 3, 313-321. https://doi.org/10.25026/jtpc.v3i4.120

Lin, L., Regenstein, J.M., Lv, S., Lu, J., Jiang, S., 2017. An overview of gelatin derived from aquatic animals: properties and modification. Trends Food Sci. Technol. 68, 102-112. https://doi.org/10.1016/j.tifs.2017.08.012.

Mahmuda, E., Idiawati, N., Wibowo, M.A., 2018. Ekstraksi gelatin pada tulang ikan belida (Chitala lopis) dengan proses perlakuan asam klorida. J. Khatulistiwa 7, 114-123.

Martianingsih, N., Atmaja, L., 2010. Analisis sifat kimia, fisik, dan termal gelatin dari ekstraksi kulit ikan pari (Himantura gerrardi) melalui variasi jenis larutan asam. Thesis, Institut Teknologi Sepuluh November.

Mustadir, M., 2015. Analisis kandungan zat gizi bakpao abon ikan kembung jantan (Rastrelliger kanagurta) dengan subtitusi rumput laut merah (Eucheuma cottonii). Thesis, Universitas Islam Negeri Alauddin Makassar.

Nurilmala, M., Jacoeb, A.M., Dzaky, R.A., 2017. Quality of cultured wader pari during storage at different temperature. J. Pengolah. Has. Perikan. Indones. 20, 339. https://doi.org/10.17844/ jphpi.v20i2.18049.

Panjaitan, T.F.C., 2016. Optimasi ekstraksi gelatin dari tulang ikan tuna (Thunnus albacares). J. Wiyata 3, 11-16.

Pertiwi, M., Atma, Y., Mustopa, A., Maisarah, R., 2018. Karakteristik fisik dan kimia gelatin dari tulang ikan patin dengan pre-treatment asam sitrat. J. Apl. Teknol. Pangan 7, 83-91. https://doi.org/10.17728/ jatp.2470.

Rachmania, R.A., Nisma, F., Mayangsari, E., 2013. Ekstraksi gelatin dari tulang ikan tenggiri melalui proses hidrolisis menggunakan larutan basa. Media Farm. J. Ilmu Farm. 10, 18-28. https://doi.org/10.12928/mf.v10i2.1167.
Santoso, C., Surti, T., Sumardianto, S., 2015. Perbedaan penggunaan konsentrasi larutan asam sitrat dalam pembuatan gelatin tulang rawan ikan pari mondol (Himantura gerrardi). J. Pengolah. dan Bioteknol. Has. Perikan. 4, 106-114.

Simpen, I.N., 2016. Karakteristik mutu gelatin dari kulit ayam broiler melalui proses perendaman kombinasi asam-basa. J. Kim. (J. of Chem.) 204-211. https://doi.org/https://doi.org/10.24843/JCHEM.2016 .v10.i02.p06.

Singkuku, F.T., Onibala, H., Agustin, A.T., 2017. Ekstraksi kolagen tulang ikan cakalang (Katsuwonus pelamis) menjadi gelatin dengan asam klorida. Media Teknol. Has. Perikan. 5, 69. https://doi.org/10.35800/mthp.5.3.2017.16846.

Suryani, N., Sulistiawati, F., Fajriani, A., Farmasi, P.S., Kesehatan, I., 2009. Kekuatan gel gelatin tipe B dalam formulasi granul terhadap kemampuan mukoadhesif. Makara, Kesehat. 13, 1-4.

Suwardi, Y., Atmaja, L., Martak, F. 2010. Pengaruh variasi larutan asam pada isolasi gelatin kulit ikan patin (Pangasius hypothalmus) terhadap sifat-sifat kimia dan fisik. Thesis, Institut Teknologi Surabaya.

Trilaksani, W., Nurilmala, M., Setiawati, I.H., 2012. Ekstraksi gelatin kulit ikan kakap merah (Lutjanus $s p$.) dengan proses perlakuan adam. J. Pengolah. Has. Perikan. Indones. 15, 240-251. https://doi.org/10.17844/jphpi.v15i3.21436.

Wijaya, O.A., Surti, T., Sumardianto, 2015. Pengaruh lama perendaman $\mathrm{NaOH}$ pada proses penghilangan lemak terhadap kualitas gelatin tulang ikan nila (Oreochromis niloticus). J. Pengolah. dan Bioteknol. Has. Perikan. 4, 25-32.

Wulandari, Supriadi, A., Purwanto, B., 2019. The Effect of Defatting and Extraction Temperature on the Physical Properties of Snakehead Fish Bone Gelatin. Fishtech 1, 28-45.

Yenti, R., Nofiandi, D., Rosmaini, 2015. Pengaruh beberapa jenis larutan asam pada pembuatan gelatin dari kulit ikan sepat rawa (Trichogaster trichopterus) kering sebagai gelatin alternatif. Sci. J. Farm. dan Kesehat. 5, 114-121. https://doi.org/10.36434/ scientia.v5i2.32 